\title{
Exposure to fine particulate matter and hospital admissions due to pneumonia: Effects on the number of hospital admissions and its costs
}

\author{
Demerval S. MoreirA ${ }^{5}$ \\ ${ }^{1}$ Medical Student, Universidade de Taubaté (Unitau), Taubaté, SP, Brazi \\ ${ }^{2}$ PhD, Department of Medicine, Unitau, Taubaté, SP, Brazil \\ ${ }^{3} \mathrm{MSc}$ in Statistics, Department of Energy, Universidade Estadual Paulista (Unesp), Campus Guaratinguetá, Guaratinguetá, SP, Brazi \\ ${ }^{4} \mathrm{BA}$ in Mathematics, Department of Energy, Unesp, Campus Guaratinguetá, Guaratinguetá, SP, Brazil \\ ${ }^{5}$ PhD - Researcher, Centro de Previsão do Tempo e Estudos Climáticos, Instituto Nacional de Pesquisas Espaciais (CPTEC-Inpe), Cachoeira Paulista, SP, Brazil
}

Nicole Vargas Patto ${ }^{1}$, luiz Fernando Costa Nascimento ${ }^{2 *}$, Katia Cristina C. Mantovani ${ }^{3}$, luciana C. P. F. S. Vieira ${ }^{4}$,

Study conducted at Departamento de Medicina, Universidade de Taubaté (Unitau), Taubaté, SP, Brazil

Article received: $1 / 5 / 2015$ Accepted for publication: 5/4/2015

*Correspondence:

Address: Av. Tiradentes, 500 Taubaté, SP - Brazil

Postal code: $12030-180$ Phone: +55 $123621-8796$

luiz.nascimento@pq.cnpq.br

http://dx.doi.org/10.1590/1806-9282.62.04.342

\section{SUMmARY}

Objective: Given that respiratory diseases are a major cause of hospitalization in children, the objectives of this study are to estimate the role of exposure to fine particulate matter in hospitalizations due to pneumonia and a possible reduction in the number of these hospitalizations and costs.

Method: An ecological time-series study was developed with data on hospitalization for pneumonia among children under 10 years of age living in São José do Rio Preto, state of São Paulo, using $\mathrm{PM}_{2.5}$ concentrations estimated using a mathematical model. We used Poisson regression with a dependent variable (hospitalization) associated with $\mathrm{PM}_{2.5}$ concentrations and adjusted for effective temperature, seasonality and day of the week, with estimates of reductions in the number of hospitalizations and costs.

Results: 1,161 children were admitted to hospital between October $1^{\text {st }}, 2011$, and September $30^{\text {th }}, 2013$; the average concentration of $\mathrm{PM}_{2.5}$ was $18.7 \mu \mathrm{g} / \mathrm{m}^{3}$ $\left(\approx 32 \mu \mathrm{g} / \mathrm{m}^{3}\right.$ of $\left.\mathrm{PM}_{10}\right)$ and exposure to this pollutant was associated with hospitalization four and five days after exposure.

Conclusion: A $10 \mu \mathrm{g} / \mathrm{m}^{3}$ decrease in concentration would imply 256 less hospital admissions and savings of approximately R $\$ 220,000$ in a medium-sized city.

Keywords: particulate matter, air pollutants, pneumonia, child health, health care costs.

\section{INTRODUCTION}

In 2012, respiratory diseases (RD) in children aged up to 10 years were responsible for 530,000 hospital admissions in Brazil, of which 96,000 occurred in the state of São Pau1o. ${ }^{1}$ These hospitalizations have cost the public health system (SUS) R 380 million, with R $\$ 85$ million being spent in São Paulo. RDs include pneumonia, bronchiolitis and asthma. Hospital admissions based on these diagnoses totaled 410,000 in Brazil and 72,000 in the state of São Paulo, generating an expense of R $\$ 280$ million in Brazil and $\mathrm{R} \$ 60$ million in the state of São Paulo (1 US\$ $\approx \mathrm{R} \$ 2.20) .{ }^{1}$

These figures show the relevance of RDs in pediatric populations both regarding number of hospital admissions and costs, in addition to a social cost that is hard to measure. Factors associated with the genesis of respi- ratory disease include exposure to air pollutants, such as particulate matter less than 10 microns in aerodynamic diameter $\left(\mathrm{PM}_{10}\right)$ and its fine fraction, $\mathrm{PM}_{2.5}$, nitrogen oxides, sulfur dioxide, ozone and carbon monoxide. Recent studies conducted in large and medium-sized cities in Brazil show that exposure to these pollutants is associated with hospitalizations for RD. ${ }^{2-11}$

These pollutants are often quantified by metering stations maintained by state environmental agencies. However, not all states have environmental agencies and, even when they do, the metering stations do not quantify all pollutants. One option would be the use of mathematical models that estimate the concentrations of air pollutants. One example is the CATT-BRAMS (Coupled Aerosol and Tracer Transport model to the Brazilian developments on 
the Regional Atmospheric Modeling System), ${ }^{12,13}$ which takes into account the atmospheric dynamics.

The application of this model for studies about the effects of pollution on human health is present in the articles by Cesar et al. ${ }^{3}$ and Ignotti et al. ${ }^{14}$ It is a mathematical model covering South America and which takes into account the emission and transport of various gases and particulate aerosols based on data obtained by satellite, generating daily estimates for different pollutants. One of the advantages of using this model is its application in cities where there are no pollution metering stations. The use of the data estimated by this system, validated by Ignotti et al., ${ }^{14}$ reduces research costs and streamlines the process of analyzing the effects of air pollution on health. The concentrations of pollutants that are estimated using this model are $\mathrm{PM}_{2.5}, \mathrm{CO}, \mathrm{NO}_{2}$ and $\mathrm{O}_{3}$, every three hours. These concentrations are estimated at a height of 40 meters above the ground in an area of $15 \times 15 \mathrm{~km}$.

The aim of our study was to estimate the role of exposure to $\mathrm{PM}_{2.5}$ in hospitalizations caused by $\mathrm{RD}$, and the reduction in the number of hospitalizations and associated costs if the concentration of this pollutant fell in the city of São José do Rio Preto, São Paulo.

\section{Method}

This is an ecological time-series study with data on hospitalizations due to pneumonia $\left(10^{\text {th }}\right.$ revision of the International Statistical Classification of Diseases and Related Health Problems - ICD-10 - J12.0 to J18.9) in children of both sexes aged up to 10 years and living in São José do Rio Preto, São Paulo. The study period was between October 1, 2011 and September 30, 2013.

Place of study: São José do Rio Preto is a municipality located in the northwest of the state of São Paulo, at an approximate distance of $450 \mathrm{~km}$ from the capital. Geographically, it is located at latitude $20^{\circ} 50^{\prime} \mathrm{S}$ and longitude $49^{\circ} 22^{\prime}$ 'W. It covers an area of $430 \mathrm{~km}^{2}$, has a population of around 400,000 inhabitants, Human Development Index (HDI) of 0.80 , and is an important regional hub, with a vehicle fleet of approximate 300,000 vehicles.

Data on hospital admissions for respiratory causes, according to place of residence, were obtained from the Ministry of Health's database, through the SUS Hospital Admission Authorizations (AIH) for the study period, month by month. The data of air pollutants were obtained from the Centro de Previsão do Tempo e Estudos Climáticos, Instituto Nacional de Pesquisas Espaciais (CPTEC-Inpe) website and refer to estimates obtained using the CATT-BRAMS (Coupled Aerosol and Tracer Transport model to the Brazilian developments on the Regional Atmospheric Modeling System) model.
The pollutant examined in this study was fine particulate matter, $\mathrm{PM}_{2.5}$.

Pearson's correlation test was used to assess possible correlation between pollutant concentrations and hospital admissions. The effects of exposure to environmental pollutants may be reflected in hospital admissions on the same day or on subsequent days. Thus, we investigated these effects on hospitalizations both on the day of exposure (lag 0 ) and within five days (lag 1 to lag 5), because there is no consensus on the size of this window. We used a Poisson generalized linear regression model, because the outcome is a discrete quantitative variable. The results of the risk of hospitalization refer to exposure to $\mathrm{PM}_{2.5}$ adjusted for day of week, seasonality and effective temperature (ET), which is a combination of temperature values (T) and relative humidity $(\mathrm{RH})$ calculated using the expression:

$$
\mathrm{ET}=\mathrm{T}-0.4^{*}(\mathrm{~T}-10)^{*}(1-\mathrm{RH} / 100)
$$

Tables were constructed with average, minimum and maximum values and the respective standard deviations for number of hospitalizations, the concentration of $\mathrm{PM}_{2.5}$ and effective temperature. The relative risks were calculated with $95 \%$ confidence intervals for hospitalization due to pneumonia in children, as well as percentage increases of these risks, resulting from an increase corresponding to $10 \mu \mathrm{g} / \mathrm{m}^{3}$ in $\mathrm{PM}_{2.5}$ concentrations. Excess hospitalizations resulting from this increase in $\mathrm{PM}_{2.5}$ and the financial costs that could cease to occur were estimated using population attributable fraction, based on the average values charged for hospitalizations due to pneumonia in the city of São José do Rio Preto, for the study period, also obtained from the Datasus website.

Strata software and a 5\% significance level were used for data analysis.

\section{Results}

1,161 children were admitted to hospital during the study period. The average, minimum and maximum values and standard deviations of the variables are shown in Table 1.

Considering that $\mathrm{PM}_{2.5}$ concentrations correspond to $60 \%$ of the $\mathrm{PM}_{10}$ concentrations, the mean values of the concentration of this pollutant would be close to 31.6 $\mu \mathrm{g} / \mathrm{m}^{3}$ ranging between 22.8 and $56.6 \mu \mathrm{g} / \mathrm{m}^{3}$ according to the average, maximum and minimum values estimated by the CATT-BRAMS for $\mathrm{PM}_{2.5}$, which were respectively $18.7,13.7$ and $33.9 \mu \mathrm{g} / \mathrm{m}^{3}$.

Coefficients and the respective $95 \%$ confidence intervals provided by the model are shown in Table 2 . The effect of exposure to $\mathrm{PM}_{2.5}$ on hospital admissions is late, having been significant four and five days after exposure. 
TABLE 1 Descriptive analysis with mean, minimum and maximum values and standard deviation (SD) of the study variables, São José do Rio Preto, SP, 2011-2013.

\begin{tabular}{lll} 
& Mean (SD) & Min - Max \\
\hline Hospitalization & $1.59(1.55)$ & $0-9$ \\
\hline $\mathrm{PM}_{2.5}\left(\mu \mathrm{g} / \mathrm{m}^{3}\right)$ & $18.7(2.8)$ & $13.7-33.9$ \\
\hline Effective temperature & $21.1(3.0)$ & $8.4-28.1$ \\
\hline
\end{tabular}

TABLE 2 Coefficients (coef) and standard error (se) obtained with Poisson regression at 0 to 5 -day lag, São José do Rio Preto, SP, 2011-2013.

\begin{tabular}{lll} 
& coef & se \\
\hline $\operatorname{lag} 0$ & 0.008609 & 0.010926 \\
\hline $\operatorname{lag} 1$ & 0.006802 & 0.011120 \\
\hline $\operatorname{lag} 2$ & -0.007561 & 0.011598 \\
\hline $\operatorname{lag} 3$ & -0.000831 & 0.011196 \\
\hline $\operatorname{lag} 4$ & $0.022547 \#$ & $0.010475 \#$ \\
\hline $\operatorname{lag} 5$ & $0.024877 \#$ & $0.010434 \#$ \\
\hline \#p-value<0.05. & &
\end{tabular}

The relative risks and respective $95 \%$ confidence intervals for increases of $10 \mu \mathrm{g} / \mathrm{m}^{3}$ in $\mathrm{PM}_{2.5}$ concentrations are shown in Figure 1. A rise of $10 \mu \mathrm{g} / \mathrm{m}^{3}$ in the concentration of $\mathrm{PM}_{2.5}$ leads to significant increase between $25 \mathrm{ppt}$ and $28 \mathrm{ppt}$ in the risk of hospitalization due to pneumonia among children four and five days after exposure.

A decline of $10 \mu \mathrm{g} / \mathrm{m}^{3}$ in the concentration of $\mathrm{PM}_{2.5}$ would lead to 256 less admissions and savings close to R\$ 220,000 within two years, considering the average cost of hospitalization at $\mathrm{R} \$ 854.00$. Note that this reduction refers to hospitalizations of children up to 10 years old and due to pneumonia.

\section{Discussion}

This study identified the role of exposure to $\mathrm{PM}_{2.5}$ in the hospitalization of children due to pneumonia, and also identified excess admissions due to increased concentration of this pollutant together with savings that would be generated if there was a decrease of $10 \mu \mathrm{g} / \mathrm{m}^{3}$ in $\mathrm{PM}_{2.5}$ concentration, also sparing the social cost of pediatric hospitalization. The risks were significantly associated hospitalizations four and five days after exposure.

$\mathrm{PM}_{2.5}$, which has an aerodynamic diameter less than 2.5 micra, is called fine fraction or fine particulate matter and can reach deeper areas in the lungs contributing with 60 to $70 \%$ of its concentration. ${ }^{15}$

The composition of the fine fraction of the particulate matter may vary according to the place of study; in São José dos Campos ${ }^{16}$ it contains the following ions: $\mathrm{NH}_{4}, \mathrm{SO}_{4}^{-2}, \mathrm{Na}$,

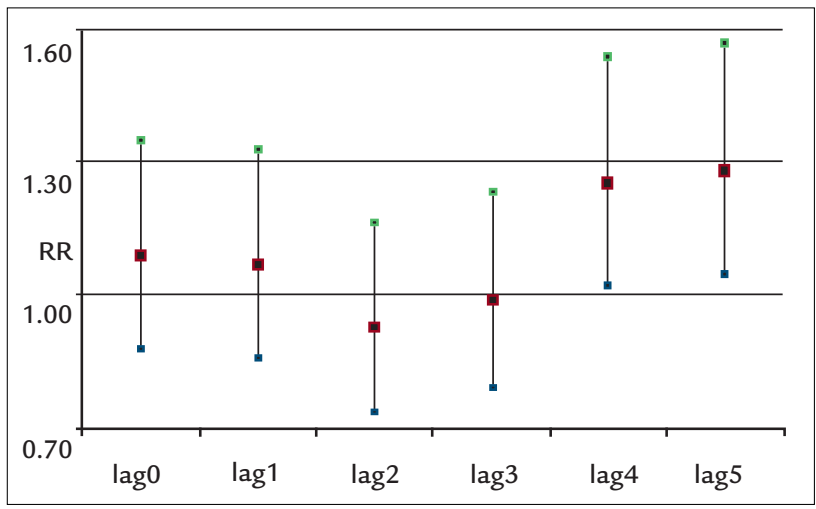

FIGURE 1 Relative risks with 95\% confidence intervals for increases in $\mathrm{PM}_{2.5}$ concentration $\left(10 \mu \mathrm{g} / \mathrm{m}^{3}\right)$ on lag days 0 to 5 . São José do Rio Preto, SP, Brazil, 2011-2013.

$\mathrm{K}, \mathrm{Cl}, \mathrm{Ca}^{+2}, \mathrm{NO}_{3}, \mathrm{H}$, and $\mathrm{Mg}^{+2} .{ }^{16}$ Metals such as $\mathrm{Al}, \mathrm{Na}, \mathrm{Si}$, $\mathrm{P}, \mathrm{K}, \mathrm{Ca}$ and polycyclic aromatic hydrocarbons (PAHs) are also part. ${ }^{17}$

Exposure to particulate matter $\mathrm{PM}_{10}$ was associated with impaired respiratory function in children in the city of Tirana, where the average concentrations of this pollutant reached $400 \mu \mathrm{g} / \mathrm{m}^{3}$, with a significant decrease in forced vital capacity and expiratory peak. ${ }^{18}$ Exposure to $\mathrm{PM}_{10}$ was also associated with hospitalizations for pneumonia among children in studies conducted in Cubatão ${ }^{7}$ and São José dos Campos. ${ }^{2}$ This information shows the relevance of exposure to $\mathrm{PM}_{10}$ and inferring the importance of the role of $\mathrm{PM}_{2.5}$ in hospitalizations for RD. In Araraquara, SP, which is a major producer of sugar and alcohol and is located about $200 \mathrm{~km}$ from São José do Rio Preto, exposure to $\mathrm{PM}_{10}$ was associated with hospitalizations for pneumonia in children, with concentrations of this pollutant $(35.7 \mu \mathrm{g} /$ $\mathrm{m}^{3}$ ) similar to the adjusted concentrations found in São José do Rio Preto $\left(31.6 \mu \mathrm{g} / \mathrm{m}^{3}\right) .{ }^{19}$

Exposures to $\mathrm{PM}_{2.5}$ were associated with hospitalizations due to bronchiolitis in a study by Sheffield et al. ${ }^{20}$ conducted between 1999 and 2007 based on the National Inpatient Sample, the largest database that evaluates hospitalization costs for bronchiolitis in the United States. In this study, the authors identified nearly 48,000 hospitalizations for bronchiolitis associated with exposure to $\mathrm{PM}_{2.5}$ and estimated a cost reduction of approximately US\$ 15 million per year, resulting from the decrease in the concentrations of this pollutant. Likewise, Carr et al. ${ }^{21}$ identified an increase of up to $15 \%$ in the chance of hospitalization for bronchiolitis with an increase of $10 \mu \mathrm{g} /$ $\mathrm{m}^{3}$ in the concentration of $\mathrm{PM}_{2.5}$ in a study conducted in Southern California between 1999 and 2005 where the average concentrations of $\mathrm{PM}_{2.5}$ were close to $25 \mu \mathrm{g} / \mathrm{m}^{3}$. 
Studies in Chile ${ }^{22}$ and the Netherlands ${ }^{23}$ highlight the role of exposure to $\mathrm{PM}_{2.5}$ in episodes of wheezing and asthma diagnosis in children.

A study conducted in Cuiabá, state of Mato Grosso, Brazil, showed that exposure to $\mathrm{PM}_{2.5}$ was associated with hospitalizations for respiratory diseases (ICD-10 J00 to J99) in children; concentrations of this pollutant were higher in the dry season than the annual average $\left(11.9 \mu \mathrm{g} / \mathrm{m}^{3}-\right.$ $7.5 \mu \mathrm{g} / \mathrm{m}^{3}$ ) and hospitalizations increased from 9.1 to $22 \%$, with the largest increases in the dry season. ${ }^{24}$ Cesar et al. ${ }^{3}$ identified the role of exposure to $\mathrm{PM}_{2.5}$ in hospitalizations in children aged up to 10 years with diagnoses of pneumonia and asthma living in Piracicaba, São Paulo, a traditional region of sugarcane production. $\mathrm{PM}_{2.5}$ concentrations were close to $29 \mathrm{\mu g} / \mathrm{m}^{3}$ with increases in the risk of hospitalization between 8 and $9 \%$ for a $10 \mu \mathrm{g} / \mathrm{m}^{3}$ rise in $\mathrm{PM}_{2.5}$, one and three days after exposure. These two studies used concentrations estimated by the CATT-BRAMS model.

Conversely, a study performed in Manaus, Amazonas, with data for $\mathrm{PM}_{2.5}$ concentrations estimated by aerosol optical depth remote sensing from MODIS ${ }^{\mathrm{TM}}$, failed to associate $\mathrm{PM}_{2.5}$ concentrations and pediatric hospitalizations, associating the pollutant to the relative humidity of air instead. Note that $\mathrm{PM}_{2.5}$ concentrations ranged from $13 \mu \mathrm{g} /$ $\mathrm{m}^{3}$ in the rainy season to $21 \mu \mathrm{g} / \mathrm{m}^{3}$ in the dry season. ${ }^{25}$

In our study, the concentrations estimated by the CATT-BRAMS were within the range of estimated values for Cuiabá, MT, and Piracicaba, SP. The increase in the concentration of $\mathrm{PM}_{2.5}$ in São José do Rio Preto would imply an increase between 23 and 26\% in the risk of hospitalization, and these increases are close to those found in Cuiaba in the dry season. ${ }^{24}$ The effect of exposure to $\mathrm{PM}_{2.5}$ appeared later in the fourth and fifth days after exposure. Our results show the role of $\mathrm{PM}_{2.5}$ in the genesis of hospitalizations due to pneumonia, unlike the results obtained in Cuiabá and Piracicaba, which included other diagnoses of respiratory diseases in the analysis.

Using population attributable fraction, we were able to estimate a decrease of approximate 256 hospitalizations with savings of approximately R 220,000 in the two years of study, if there was a reduction in $\mathrm{PM}_{2.5}$ of $10 \mu \mathrm{g} / \mathrm{m}^{3}$. These values of the attributable fraction are higher than those obtained by Marcílio and Gouveia, authors who studied children under five years old in seven Brazilian cities. ${ }^{26}$

As for hospital admissions, despite the figures being low, it should be noted that this reduction only refers to the hospitalizations of children under 10 years old with pneumonia in a city of about 400,000 inhabitants served by the Unified Health System. One has to consider the harmful effects of exposure in the adult population whose admissions could be due to other respiratory diseases such as asthma and complications of chronic obstructive pulmonary disease and cardiovascular diseases such as hypertension, myocardial infarction and stroke.

As for the reduction of financial costs with decreasing concentrations of air pollutants, Ostro and Chestnut ${ }^{27}$ calculated savings close to US\$ 70 billion if the average concentrations of $\mathrm{PM}_{2.5}$ were $12 \mu \mathrm{g} / \mathrm{m}^{3}$. In addition, a reduction of $10 \mu \mathrm{g} / \mathrm{m}^{3}$ in $\mathrm{PM}_{2.5}$ concentration would imply an average increase in life expectancy of $0.6( \pm 0.2)$ years, possibly contributing to an increase of about $15 \%$ in certain areas of the USA. ${ }^{28}$ Miraglia and Gouveia used the DALY method to estimate that exposure to $\mathrm{PM}_{10}$ caused approximately 20,000 deaths in 29 Brazilian cities plus greater area, with a cost of US\$ 1.7 billion per year. ${ }^{29}$

\section{LIMITATIONS}

This study may have limitations such as those derived from the nature of ecological studies, namely: It is not possible to identify the causality between exposure and outcome, but only to point out associations between exposures and outcomes; identifying if the person who was hospitalized was exposed, and if the person exposed was hospitalized is not possible; errors in diagnoses registered in the Datasus are not considered, leading to underreporting or overreporting of cases of pneumonia in children. Children served by health plans and those treated in outpatient settings were not included.

Moreover, the Datasus does not include information on factors associated with pneumonia in children such as passive smoking, low birth weight, lack of breastfeeding, and more. Concentrations were considered homogeneous throughout the city and the authors assumed that children were exposed homogeneously to the pollutants. The amounts of pollutants were obtained using a mathematical model, with a good correlation identified between these and actual data. ${ }^{13}$ However, there may be a degree of uncertainty in the estimation of these data. The use of this data is recorded in two recent articles ${ }^{3,24}$ and proved to be quite adequate, with few flaws in the quantification of values. Relevant findings included the confirmation of the important role of exposure to $\mathrm{PM}_{2.5}$ in the number of hospitalization and that the reduction in $\mathrm{PM}_{2.5}$ concentration can reduce the financial costs. Also important is the analysis of the role of exposure to $\mathrm{PM}_{2.5}$ in hospitalizations for respiratory disease that is little studied in Brazilian articles.

The results of our study, conducted in a mediumsized city, revealed the role of exposure to $\mathrm{PM}_{2.5}$ in hospitalizations due to RD and the decline in both the number of hospitalizations and their associated cost with a 
$10 \mu \mathrm{g} / \mathrm{m}^{3}$ decrease in this pollutant's concentration. The implementation of policies to reduce these concentrations would certainly reduce the impact on hospitalizations, not only among children with $\mathrm{RD}$, but possibly among adults with this and other respiratory diseases.

\section{AcKNOWLedgment}

Nicole Vargas Patto thanks the São Paulo Research Foundation for the scholarship grant 2013/19430-5.

\section{Resumo}

Exposição ao material particulado fino e internações por pneumonias. Efeitos no número de internações e em seus custos

Objetivo: como as doenças do aparelho respiratório são importantes causas de internação em crianças, os objetivos deste estudo são estimar o papel da exposição ao particulado fino nas internações por pneumonias e a possível redução do número dessas internações e de seus custos.

Método: um estudo ecológico de séries temporais foi desenvolvido com dados de internação por pneumonias em crianças de até 10 anos de idade, residentes em São José do Rio Preto, SP, utilizando concentrações de $\mathrm{PM}_{2,5}$ estimadas por modelo matemático. Foi utilizada a regressão de Poisson com a variável dependente - internação, sendo associada às concentrações de $\mathrm{PM}_{2,5}$, ajustada por temperatura efetiva, sazonalidade e dia da semana e foram estimadas reduções no número de internações e em seus custos. Resultados: foram internadas 1161 crianças entre 01.10.2011 e 30.09.2013. A concentração média de $\mathrm{PM}_{2,5}$ foi de $18,7 \mu \mathrm{g} /$ $\mathrm{m}^{3}\left(\approx 32 \mu \mathrm{g} / \mathrm{m}^{3}\right.$ de $\left.\mathrm{PM}_{10}\right)$ e a exposição a esse poluente foi associada à internação 4 e 5 dias após a exposição.

Conclusão: redução em $10 \mu \mathrm{g} / \mathrm{m}^{3}$ em sua concentração implicaria redução de 256 internações e de aproximados R\$ 220 mil em uma cidade de porte médio.

Palavras-chave: material particulado, poluentes do ar, pneumonia, saúde da criança, custos de cuidados de saúde.

\section{References}

1. Brasil. Ministério da Saúde. Departamento de Informática do SUS (Datasus). [cited 2014 Sep 09]. Available from: http://tabnet.datasus.gov.br/cgi/tabcgi. exe?sih/cnv/nruf.def.

2. Nascimento LFC, Pereira LAA, Braga ALF, Módolo MCC, Carvalho Jr JA. [Effects of air pollution on children's health in a city in Southeastern Brazil]. Rev Saúde Pública. 2006; 40(1):77-82.

3. Cesar ACG, Nascimento LFC, Carvalho Jr JA. [Association between exposure to particulate matter and hospital admissions for respiratory disease in children]. Rev Saúde Pública. 2013; 47(6):1209-12.

4. Negrisoli J. Nascimento LFC. Atmospheric pollutants and hospital admissions due to pneumonia in children. Rev Paul Pediatr. 2013; 31(4):501-6.

5. Amâncio CT, Nascimento LFC. Asthma and air pollutants: a time series study. Rev Assoc Med Bras. 2012; 58(3):302-7.
6. Gouveia N, Freitas CU, Martins LC, Marcilio IO. Hospitalizações por causas respiratórias e cardiovasculares associadas á contaminação atmosférica no Município de São Paulo, Brasil. Cad Saúde Pública. 2006; 22(12):2669-77.

7. Jasinski R, Pereira LAA, Braga ALF. Poluição atmosférica e internações hospitalares por doenças respiratórias em crianças e adolescentes em Cubatão, São Paulo, Brasil, entre 1997 e 2004. Cad Saúde Pública. 2011; 27(11): 2242-52.

8. Moura M, Junger WL, Mendonça GAS, Leon AP. Qualidade do ar e transtornos respiratórios agudos em crianças. Rev Saúde Pública. 2008; 42(3):503-11.

9. Riguera D, André PA, Zanetta DMT. Poluição da queima de cana e sintomas respiratórios em escolares de Monte Aprazível, SP. Rev Saúde Pública. 2011; 4(5):878-86.

10. Ignotti E, Hacon SS Junger WL, Mourão D, Longo K, Freitas S, et al. Air pollution and hospital admissions for respiratory diseases in the subequatorial Amazon: a time series approach. Cad. Saúde Pública. 2010; 26(4):747-61.

11. Castro HA, Cunha MF, Mendonça GAS, Junger WL, Cunha-Cruz J, Leon AP. Efeitos da poluição do ar na função respiratória de escolares, Rio de Janeiro, RJ. Rev Saúde Pública. 2009; 43(1):26-34

12. Longo KM, Freitas SR, Setzer A, Prins E, Artaxo P, Andreae MO. The Coupled Aerosol and Tracer Transport model to the Brazilian developments on the Regional Atmospheric Modeling System (CATT-BRAMS). Part 2: model sensitivity to the biomass burning inventories. Atmo Chem Phys Discuss. 2007; 7:8571-96.

13. Freitas SR, Longo KM, Dias MAFS, Chatfield R, Dias PLS, Artaxo P, et al. The Coupled Aerosol and Tracer Transport model to the Brazilian developments on the Regional Atmospheric Modeling System (CATTBRAMS). Part 1: Model description and evaluation. Atmos Chem Phys Discuss. 2007; 7:8525-69.

14. Ignotti E, Valente JG, Longo KM, Freitas SR, Hacon SS, Netto PA. Impact on human health of particulate matter emitted from burning in the Brazilian Amazon region. Rev Saúde Pública. 2010; 44(1):121-30.

15. Donaldson K, Stone V, Clouter A, MacNee W. Ultrafine particles. Occup Environ Med. 2001; 58(3):211-6.

16. Souza PA, Mello WZ, Mariani RL, Sella SM. Caracterização do material particulado fino e grosso e composição da fração inorgânica solúvel em água em São José dos Campos (SP). Química Nova. 2010; 33(6):1247-53.

17. Riva DR, Magalhães CB, Lopes AA, Lanças T, Mauad T, Malm O, et al. Low dose of fine particulate matter (PM2.5) can induce acute oxidative stress, inflamation and pulmonar impairment in healthy mice. Inhal Toxicol. 2011; 23(5):257-67.

18. Tabaku A, Bejtja G, Bala S, Toci E, Resuli J. Effects of air pollution on children's pulmonary health. Atmos Environ. 2011; 45(40):7540-5.

19. Souza LSV, Nascimento LFC. Air pollutants and hospitalar admission due to pneumonia in children. A time serie study. Rev Assoc Med Bras. 2015 (no prelo)

20. Sheffield P, Roy A, Wong K, Trasande L. Fine particulate matter pollution linked to respiratory illness in infants and increased hospital costs. Health Aff (Millwood). 2011; 30(5):871-8

21. Karr C, Lumley T, Schreuder A, Davis R, Larson T, Ritz, et al. Effects of subchronic and chronic exposure to ambient air pollutants on infant bronchiolitis. Am J Epidemiol. 2007; 165(5):553-60.

22. Pino P, Walter T, Oyarzum M, Villegas R, Romieu I. Fine particulate matter and whezzing illnesses in the first year of life. Epidemiol. 2004; 15(6):702-6.

23. Brauer M, Hoek G, Van Vliet P, Meliefste K, Fischer PH, Wijga A, et al. Air pollution from traffic and the development of respiratory infections and asthmatic and allergic symptoms in children. Am J Respir Crit Care Med. 2002; 166(8):1092-8.

24. Silva AMC, Mattos IE, Ignotti E, Hacon SS. Material particulado originário de queimadas e doenças respiratórias. Rev Saúde Pública. 2013; 47(2):345-52.

25. Andrade-Filho VS, Artaxo P, Hacon S, Carmo CN, Cirino G. Aerossóis de queimadas e doenças respiratórias em crianças, Manaus, Brasil. Rev Saúde Pública. 2013; 47(2):239-47.

26. Marcílio I, Gouveia N. Quantifying the impact of air pollution on the urban population of Brazil. Cad Saúde Pública. 2007; 23(suppl 4):s529-36.

27. Ostro B, Chestnut L. Assessing the health benefits of reducing particulate matter air pollution in the United States. Environ Res. 1998; 76(2):94106.

28. Pope CA 3rd, Ezzati M, Dockery DW. Fine-particulate air pollution and life expectancy in the United States. N Engl J Med. 2009; 360(4):376-86.

29. Miraglia SGEK, Gouveia N. Custos da poluição atmosférica nas regiões metropolitanas brasileiras. Ciênc Saúde Colet. 2014; 19(10):4141-7. 